\title{
A Case of Niemann-Pick type B Presented with Interstitial Lung Disease
}

\section{Interstisyel Akciğer Hastalığı ile Prezente Olan Niemann-Pick Tip B Olgusu}

Gülşah Günlüoğlu', Pelin Pamir', Ayşe Yeter', Elif Yelda Özgün Niksarlıoğlu', Merve Dilşad Gün', Nurcan Ünver², Güngör Çamsarı'

\section{Abstract}

Niemann-Pick disease is a rare lysosomal storage disease in which sphingolipids accumulate in reticuloendothelial cells due to acid sphingomyelinase deficiency, three forms of which have been defined to date. Since Niemann-Pick Type B has different clinical findings, the patient presentation and disease progression can differ. Lipid storage is slow and progressive and leads to deterioration in multiple organs. Patients are mostly diagnosed in adulthood and pulmonary involvement is common. In our case, a 32 year-old female patient with complaints of cough and dyspnea was on long-term follow-up with a prediagnosis of interstitial lung disease, but with no specific diagnosis as she declined invasive procedures. An open lung biopsy performed due to the progression of symptoms resulted in histiocytes with foamy cytoplasm. A diagnosis of Niemann-Pick Type $B$ was subsequently reached after a large patchy, mild hypocellular bone marrow with histiocytic infiltration, compatible with storage disease, was identified from a bone marrow biopsy performed for splenomegaly and thrombocytopenia. Since storage diseases are rare they are not considered in the differential diagnosis of interstitial lung diseases, but should be considered in the presence of systemic symptoms.

Key words: Niemann-Pick, storage disease, interstitial lung disease, splenomegaly, thrombocytopenia.

\section{Özet}

Niemann-Pick hastalığı, asit sfingomiyelinaz eksikliği sonucu retiküloendotelyel hücrelerde sfingolipidlerin biriktiği nadir bir lizozomal depo hastalığıdır. Üç formu tanımlanmıştır. Niemann-Pick tip B, farklı ağırlıkta klinik bulgulara sahip olduğundan hastaların prezentasyonu ve hastalık progresyonu farklıdır. Lipid depolanma yavaş ve progresif olup multipl organda bozulma oluşturur. Hastalar çoğunlukla erişkin yaşta tanı alırlar ve pulmoner tutulum sıklıkla görülür. Olgumuz, 32 yaşında kadın hasta, öksürük ve dispne şikayetleri ile başvurusu sonrası interstisyel akciğer hastalığı ön tanısı ile, girişimsel işlemi kabul etmediğinden spesifik tanı almadan uzun süredir takip edilmekteydi. Semptomlarında progresyon olması nedeni ile yapılan açık akciğer biyopsisi, köpüksü sitoplazmalı histiyositler olarak sonuçlandı. Sonrasında splenomegali ve trombositopeni nedeni ile yapılan kemik iliği biyopsisinde geniş yama tarzında depo hastalığı ile uyumlu histiyositik infiltrasyon gösteren hafif hiposellüler kemik iliği görülmesi sonucu, Niemann-Pick tip B tanısına ulaşıldı. Depo hastalıkları nadir görülmesi sebebi ile interstisyel akciğer hastalıkları ayırıcı tanısında ön planda düşünülmemekle birlikte sistemik semptom varlığında akla getirilmelidir.

Anahtar Sözcükler: Niemann-Pick, depo hastalığı, interstisyel akciğer hastalığı, splenomegali, trombositopeni.

'Department of Chest Disease, Yedikule Chest Diseases and Thoracic Surgery Training and Research Hospital, Istanbul, Turkey

${ }^{2}$ Department of Pathology, Yedikule Chest Diseases and Thoracic Surgery Training and Research Hospital, Istanbul, Turkey

'Yedikule Göğüs Hastalıkları ve Göğüs Cerrahisi Eğitim ve Araşıırma Hastanesi, Göğüs Hastalıkları Anabilim Dalı, İstanbul

${ }^{2}$ Yedikule Göğüs Hastalıkları ve Göğüs Cerrahisi Eğitim ve Araştırma Hastanesi, Patoloji Anabilim Dalı, İstanbul

Submitted (Başvuru tarihi): 07.03.2021 Accepted (Kabul tarihi): 14.05.2021

Correspondence (iletişim): Pelin Pamir, Department of Chest Disease, Yedikule Chest Diseases and

Thoracic Surgery Training and Research Hospital, Istanbul, Turkey

e-mail: pamirpelin@hotmail.com

*This case report was accepted and presented as an Electronic Poster presentation at 23th Annual Congress of Turkish Thoracic Society October 15-18, 2020. 
Acid sphingomyelinase deficiency (ASMD) is a rare lysosomal storage disease with autosomal recessive inheritance caused by a mutation in the SMPDI gene, and is known also as Niemann-Pick disease $(1,2)$. The clinical and pathological features of disease were described in the early-20th century by German pediatrician Albert Niemann, German clinician Ludwig Pick, and later Crocker and Farber $(3,4)$. In this disease, abnormal lipid (sphingomyelin) storage is seen in reticuloendothelial macrophages. Its incidence is 0.5 per 100,000 births, and three subtypes have been identified to date: Type $A$, acute neurovisceral form; Type $B$, chronic visceral form; In Type A/B: chronic neurovisceral intermediate form and Type $C$, although it has the same name, cholesterol accumulation occurs in tissues as a result of defects in intracellular transport and processing of cholesterol, not sphingomyelin.

In Type B, diagnosis is usually made in infancy or childhood based on the detection of hepatosplenomegaly, and patients generally survive until adulthood, when pulmonary involvement becomes common. Other common clinical signs include liver dysfunction, heart disease, hematological abnormalities, skeletal abnormalities and growth delays (5). Diagnosis is based on the measurement of sphingomyelinase activity in leukocytes, liver and bone marrow biopsies, and observations of foamy macrophages. We present here a 32-year-old female patient who did not receive a specific diagnosis for a long time who was followed up for interstitial lung disease, and who was diagnosed with NPD-B after bone marrow open lung biopsy was conducted in the light of the literature.

\section{CASE}

A 32-year-old female patient was admitted to our hospital for the first time in 2013 with complaints of cough and dyspnea. The patient was living in Istanbul and was employed as a plane cleaner. She was a non-smoker, and there was no additional disease. At the time of her first presentation in 2013, WBC: $5.06 \times 10^{3} / \mathrm{mm}^{3}$, RBC: 4.87x106/ $\mathrm{mm}^{3}$, HGB: $12.2 \mathrm{~g} / \mathrm{dl}, \mathrm{HCT}: 37.7 \%, \mathrm{MCV}$ : 77.5 $\mu$, PLT: $139 \times 10^{3} / \mathrm{mm}^{3}, \mathrm{FEV} 1: 2.61 \mathrm{~L}$ (83\%), FVC: $2.63 \mathrm{~L}(72 \%)$ and \%FEV1: 99\%. There was a diffuse reticular pattern on chest radiography, and a highresolution computed tomography (HRCT) (Figure la, b and c) revealed interlobular septal thickening and centriacinar nodules in all common zones. The patient declined any invasive procedures and so continued outpatient clinic follow-ups for four years due to the onset of occasional mild progressive dyspnea. In 2019, when her symptoms and radiology progressed, an open lung biopsy was performed, and the pre-procedural hemogram revealed WBC: $7.22 \times 10^{3} / \mathrm{mm}^{3}$, RBC: $5.04 \times 106 / \mathrm{mm}^{3}$, HGB: $12.7 \mathrm{~g} / \mathrm{dl}, \mathrm{HCT}: 38.7 \%$, MCV: $76.8 \mu$, PLT: $138 \times 10^{3} / \mathrm{mm}^{3}$; respiratory function test; FEV1: 1,97 L (\%74), FVC: 2,00 L (\%65), \%FEV1: 92,6\% and DLCO $2.21 \mathrm{~L}(30 \%)$.

The pathology of left lower lobe wedge resection was reported as a hyalinized calcified nodular area, and foamy cytoplasm in the alveolar area in the surrounding lung parenchyma (Figure 2). No specific diagnosis could be reached based on these results, but after consulting with the pathology unit, it was decided that the patient should be investigated for systemic diseases. In the meantime, splenomegaly and thrombocytopenia were detected in the internal medicine outpatient clinic where the patient applied for another reason, and a bone marrow biopsy was performed. The bone marrow biopsy pathology result was reported as mild hypocellular bone marrow showing histiocytic infiltration compatible with large patchy storage disease. Since a deficiency in sphingomyelinase enzyme activity was detected, the patient was diagnosed with Niemann-Pick disease Type B, and when lung preparations were re-consulted with pathology, the abundant histiocyte communities were stated to support storage disease involvement.

The patient now has significant dyspnea and cough complaints, and although she has been using methylprednisolone $16 \mathrm{mg} /$ day for a while, her symptoms are continuing.

\section{DISCUSSION}

In acid sphingomyelinase deficiency (ASMD), abnormal lipid (sphingomyelin) deposition is observed in reticuloendothelial macrophages. These cells are 50-90 $\mu \mathrm{m}$ and have a foamy appearance (6).

Since Niemann-Pick disease Type B, unlike Type A, has wide phenotypic heterogeneity and clinical findings of different severity, the presentation and disease progression of patients can differ. Patients are mostly diagnosed in adulthood, when lipid storage is slow and progressive and leads to deterioration in multiple organs, being most commonly deposited in the liver, spleen, lymph nodes, adrenal cortex and lungs. The most frequent findings at first presentation are splenomegaly (78\%) and hepatomegaly (73\%). With varying degrees of lung involvement, shortness of breath and recurrent pulmonary infections may also be presenting symptoms (42\%) (7), and atherogenic lipid profile, hematology abnormalities, liver dys- 
function, heart disease, skeletal abnormalities and growth delay may also be observed (5).

Diagnosis is based on the measurement of sphingomyelinase activity in leukocytes, liver and bone marrow biopsies. The presence of foamy macrophages in the bone marrow and liver biopsies is also diagnostic. Our patient had pulmonary involvement, splenomegaly and thrombocytopenia, and was diagnosed with Niemann-Pick disease after observing foamy histiocytes in the bone marrow and lung biopsies. Since the patient had reached adulthood and no neurological involvement was detected, the subtype was determined as $\mathrm{B}$.

Pulmonary involvement in NPD Type $B$ is seen at a rate of $90-98 \%(7,8)$ and the lower lobe is dominant. The clinical picture can range from mild symptoms to a more chronic form $(9,10)$. The most commonly reported respiratory symptoms are dyspnea upon mild exertion and recurrent infections. Some studies have reported that lung disease is the clinical feature with the worst effect on the patient's clinic in NPD-B patients.

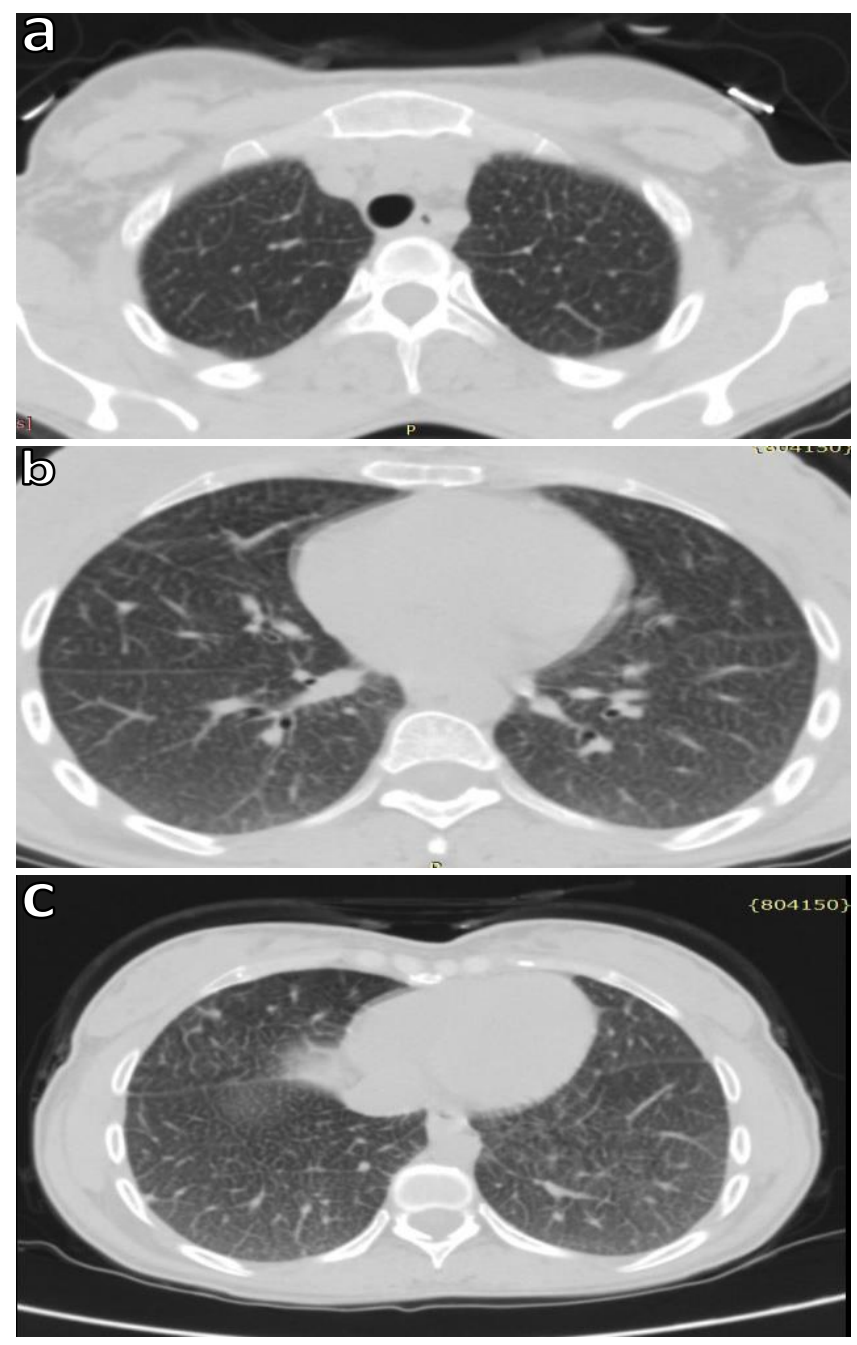

Figure 1: Interlobular septal thickening and centriacinar nodules in all common zones $(a, b, c)$

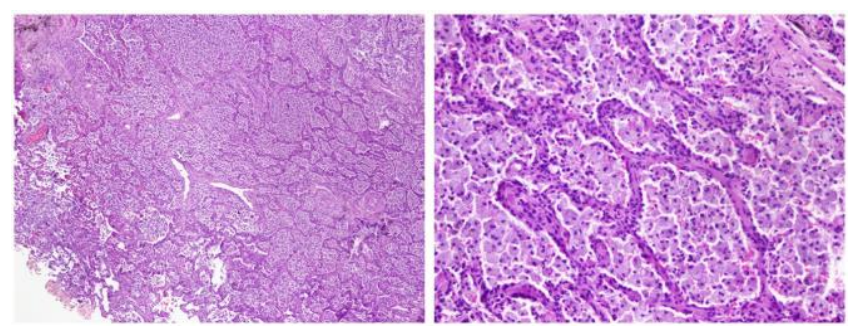

Figure 2: Histiocytes with foamy cytoplasm filling the alveoli and interstitium on wedge biopsy (Hematoxylin Eosin, x40, x100)

In a multi-center study in which 53 NPD-B patients (mean age 23.3 years) were examined prospectively, 47/53 (90\%) and 51/53 (98\%) were found to have interstitial lung disease based on chest radiography and $\mathrm{CT}$, respectively (8), and the authors concluded that the lung is the most commonly affected organ in all age groups in patients with NPD-B. In another study, various degrees of ILD findings (ground glass, reticulonodular densities, pleural thickening and decreased lung volume) were found in almost all patients (90\%; 53/59) (7). Although pulmonary involvement is common, it is a fact that pulmonologists do not consider storage diseases in the foreground in the differential diagnosis of ILD due to the different clinical spectrum. When our patient was reevaluated retrospectively following diagnosis, the presence of splenomegaly in the upper abdominal sections of a lung tomography and low platelets in the hemogram were observed.

The radiological follow-up of patients diagnosed with NPD Type B is also recommended (8). Although it has been reported that interstitial pattern density and respiratory dysfunction are not correlated (8), it has been observed that patients with dyspnea in particular have lower FVC and DLCOs than those without (7). Furthermore, the annual pulmonary functional loss has been observed to be quite low in observational studies (11), which suggest that involvement is not in the form of progressive pulmonary fibrosis. In our patient, no significant decrease was noted in vital capacity during long-term follow-up, and despite prolonged radiological and functional stabilization, there was a marked progression of cough symptoms. Lipid-loaded macrophages can be observed in bronchoalveolar fluid, but are not specific for NPD. Especially in open lung biopsy, the appearance of lipid-loaded histiocytes stained dark blue with May-Grünwald-Giemsa supports a diagnosis of Niemann-Pick (sea blue histiocytes). Since the diagnosis of NPD was obtained later in life in our patient, an open lung biopsy was performed initially for the etiology of interstitial lung disease, and histiocytes with foamy cytoplasm were observed in the 
alveolar area. The need for a lung biopsy in the presence of appropriate radiological findings in patients diagnosed with storage disease is controversial, as the risks associated with invasive interventions may be greater than the benefit, especially in patients without significant functional deterioration.

Although there is no effective treatment for Type B, limited success has been achieved in the small number of patients who underwent bone marrow and stem cell transplantation (12). Clinical studies have been conducted involving gene therapies and enzyme replacement therapy, and whole lung lavage has been reported in cases of lipoid pneumonia (13).

\section{CONCLUSION}

Due to the rarity of storage diseases and their wide heterogeneity, they may not be considered by the clinician dealing with interstitial lung disease in a differential diagnosis, although the systematic evaluation of patients is very important. As in our case, it is very important to evaluate patients with interstitial lung disease in a multidisciplinary manner in the presence of additional system findings.

\section{CONFLICTS OF INTEREST}

None declared.

\section{AUTHOR CONTRIBUTIONS}

Concept - G.G., P.P., A.Y., E.Y.Ö.N., M.D.G., N.Ü., G.Ç.; Planning and Design - G.G., P.P., A.Y., E.Y.Ö.N., M.D.G., N.Ü., G.Ç.; Supervision - G.G., P.P., A.Y., E.Y.Ö.N., M.D.G., N.Ü., G.Ç.; Funding - G.G., P.P., A.Y., E.Y.Ö.N., M.D.G., N.Ü., G.Ç.; Materials - G.G., P.P., A.Y., E.Y.Ö.N., M.D.G., N.Ü., G.Ç.; Data Collection and/or Processing - G.G., P.P., A.Y., E.Y.Ö.N., M.D.G., N.Ü., G.Ç.; Analysis and/or Interpretation G.G., P.P., A.Y., E.Y.Ö.N., M.D.G., N.Ü., G.Ç.; Literature Review - G.G., P.P., A.Y., E.Y.Ö.N., M.D.G., N.Ü., G.Ç.; Writing - G.G., P.P., A.Y., E.Y.Ö.N., M.D.G., N.Ü., G.Ç.; Critical Review - G.G., P.P., A.Y., E.Y.Ö.N., M.D.G., N.Ü., G.Ç.

\section{YAZAR KATKILARI}

Fikir - G.G., P.P., A.Y., E.Y.Ö.N., M.D.G., N.Ü., G.Ç.; Tasarım ve Dizayn - G.G., P.P., A.Y., E.Y.Ö.N., M.D.G., N.Ü., G.Ç.; Denetleme - G.G., P.P., A.Y., E.Y.Ö.N., M.D.G., N.Ü., G.Ç.; Kaynaklar - G.G., P.P., A.Y., E.Y.Ö.N., M.D.G., N.Ü., G.Ç.; Malzemeler - G.G., P.P., A.Y., E.Y.Ö.N., M.D.G., N.Ü., G.Ç.; Veri Toplama ve/veya İşleme - G.G., P.P., A.Y., E.Y.Ö.N., M.D.G., N.Ü., G.Ç.; Analiz ve/veya Yorum - G.G., P.P., A.Y., E.Y.Ö.N., M.D.G., N.Ü., G.Ç.; Literatür Taraması - G.G. P.P., A.Y., E.Y.Ö.N., M.D.G., N.Ü., G.Ç.; Yazıyı Yazan G.G., P.P., A.Y., E.Y.Ö.N., M.D.G., N.Ü., G.Ç.; Eleştirel Inceleme - G.G., P.P., A.Y., E.Y.Ö.N., M.D.G., N.Ü., G.Ç.

\section{REFERENCES}

1. Schuchman EH, Desnick RJ. Niemann Pick Disease Types A and B: Acid sphingomyelinase deficiencies. In: Scriver CR, Beaudet AL, Sly WS, Valle D, eds. The Metabolic \& Molecular Bases of Inherited Disease. 8th ed. McGraw Hill; New York; 2001:3589-3610.

2. Spence M, Callahan J. Sphingomyelin-cholesterol lipidoses: The Niemann Pick group of diseases. McGraw-Hill; New York: 1989.

3. Swaiman KF, Ashwal S. Pediatric Neurology. 3rd ed. St Louis, Missouri: 1999;273:447-9.

4. Pentchev PG, Vanier MT, Suzuki K, Patterson MC. Niemann Pick type C: A cellular cholesterol lipidosis. In: Charles RS, Arthur LB, William SS, David V eds. The metabolic and molecular bases of inherited disease. Vol 2, 1995:2625-29.

5. McGovern MM, Avetisyan R, Sanson BJ, Lidove O. Disease manifestations and burden of illness in patients with acid sphingomyelinase deficiency (ASMD). Orphanet J Rare Dis 2017;12:1-13. [CrossRef]

6. Watts RWE. Lysosomal storage disease. In: Weatherall DJ, Warrell DA, eds. Oxford textbook of medicine. 3rd ed. Oxford University Press; 1996:1426-37.

7. McGovern MM, Wasserstein MP, Giugliani R, Bembi B, Vanier MT, Mengel E, et al. A prospective, crosssectional survey study of the natural history of NiemannPick disease type B. Pediatrics 2008; 122:341-49. [CrossRef]

8. Mendelson DS, Wasserstein MP, Desnick RJ, Glass R, Simpson W, Skloot $G$, et al. Type B Niemann-Pick disease: findings at chest radiography, thin-section $C T$, and pulmonary function testing. Radiology 2006; 238:33945. [CrossRef]

9. Minai OA, Sullivan EJ, Stoller JK. Pulmonary involvement in Niemann-Pick disease: case report and literature review. Respir Med 2000; 94:1241-51. [CrossRef]

10. von Ranke FM, Pereira Freitas HM, Mancano AD, Rodrigues RS, Hochhegger B, Escuissato D, et al. Pulmonary involvement in Niemann-Pick disease: a state-ofthe-art review. Lung 2016; 194:511-8. [CrossRef] 
11. Wasserstein MP, Desnick RJ, Schuchman EH, Hossain S, Wallenstein S, Lamm C, et al. The natural history of type B Niemann-Pick disease: results from a 10-year longitudinal study. Pediatrics 2004; 114:672-7. [CrossRef]

12. Bayever E, Kamani N, Ferreira P, Machin GA, Yudkoff M, Conard $\mathrm{K}$, et al. Bone marrow transplantation for Nie-
mann-Pick type 1A disease. J Inherit Metab Dis 1992; 15:919-28. [CrossRef]

13. Nicholson AG, Wells AU, Hooper J, Hansell DM, Kelleher A, Morgan C. Successful treatment of endogenous lipoid pneumonia due to Niemann-Pick type B disease with whole-lung lavage. Am J Respir Crit Care Med 2002; 165:128-31. [CrossRef] 